\title{
Two New Copper(II) Complexes of 1-Butyl-1H-1,2,4-triazole: Synthesis, Characterization and Electrocatalytic Activity
}

\author{
Ke Fei Wang, Fang Fang Jian* and Rui Rui Zhuang
}

\author{
New Materials \& Function Coordination Chemistry Laboratory, Qingdao University of Science and \\ Technology, Qingdao Shandong 266042, People's Republic of China
}

\begin{abstract}
Dois novos complexos de cobre(II), $\left[\mathrm{Cu}_{4} \mathrm{Cl} \mathrm{O}_{6} \mathrm{O}\left(\mathrm{C}_{6} \mathrm{H}_{11} \mathrm{~N}_{3}\right)_{4}\right]$ e $\left[\mathrm{CuBr}_{2}\left(\mathrm{C}_{6} \mathrm{H}_{11} \mathrm{~N}_{3}\right)_{4}\right]$, foram sintetizados e caracterizados por difratometria de raios $\mathrm{X}$ de monocristal, espectroscopia de absorção no infravermelho e análise elementar. Os compostos apresentaram voltamogramas cíclicos similares e boas atividades eletrocatalíticas com relação à redução de peróxido de hidrogênio e ácido tricloroacético. Os limites de detecção, a faixa linear de calibração e as sensibilidades dos eletrodos são, respectivamente, $0,01 \mu \mathrm{mol} \mathrm{L} \mathrm{L}^{-1}, 0,02$ a $0,20 \mu \mathrm{mol} \mathrm{L} \mathrm{L}^{-1}$ e $98,80 \mu \mathrm{A} \mu \mathrm{mol} \mathrm{L}^{-1}$ para o peróxido de hidrogênio e $0,01 \mu \mathrm{mol} \mathrm{L} \mathrm{L}^{-1}, 0,02$ a $0.20 \mu \mathrm{mol} \mathrm{L}^{-1}$ e $80,05 \mu \mathrm{A} \mu \mathrm{mol} \mathrm{L}^{-1}$ para o ácido tricloroacético.
\end{abstract}

Two new copper(II) complexes, $\left[\mathrm{Cu}_{4} \mathrm{Cl}_{6} \mathrm{O}\left(\mathrm{C}_{6} \mathrm{H}_{11} \mathrm{~N}_{3}\right)_{4}\right](\mathbf{1})$ and $\left[\mathrm{CuBr}_{2}\left(\mathrm{C}_{6} \mathrm{H}_{11} \mathrm{~N}_{3}\right)_{4}\right]$ (2), were synthesized and characterized by single crystal $\mathrm{X}$-ray diffractometry, IR spectroscopy and elemental analysis. They were used as bulk modifiers for the fabrication of two carbon paste electrodes $(\mathrm{Cu}-$ CPE): 1-CPE and 2-CPE. They had similar electrochemical behaviors characterized by cyclic voltammetry and good electrocatalytic activities toward the reduction of hydrogen peroxide and trichloroacetic acid. The detection limits, linear calibration ranges and sensitivities were respectively $0.01 \mu \mathrm{mol} \mathrm{L}{ }^{-1}, 0.02$ to $0.20 \mu \mathrm{mol} \mathrm{L} \mathrm{L}^{-1}$ and $98.80 \mu \mathrm{A} \mu \mathrm{mol} \mathrm{L}^{-1}$ for hydrogen peroxide detection, and $0.01 \mu \mathrm{mol} \mathrm{L}-1,0.02$ to $0.20 \mu \mathrm{mol} \mathrm{L}^{-1}$ and $80.05 \mu \mathrm{A} \mu \mathrm{mol} \mathrm{L}^{-1}$ for trichloroacetic acid detection.

Keywords: copper complexes, electrochemistry, electrocatalysis, hydrogen peroxide, trichloroacetic acid

\section{Introduction}

Application of chemically modified electrodes (CMEs) in electrochemical determinations has been widely considered as a sensitive and selective analytical method for the detection of trace amounts of many compounds. ${ }^{1-3}$ One of the most important properties of CMEs, in comparison to unmodified electrodes, is their ability to catalyze the electrode process with significant decrease of the needed overpotential. Metal complexes are well recognized for their excellent electrocatalytic properties toward the detection of hydrogen peroxide, ${ }^{4-6}$ nitrite,${ }^{4-7}$ bromate ${ }^{5-7}$ and trichloroacetic acid, ${ }^{8}$ among other analytes. The wide range of electrochemical applications of metal complexes as, e.g, electrocatalysts for development of novel sensors and ion-carriers in ion-selective electrodes, has been reviewed. ${ }^{9}$

Recently, great efforts have been directed toward the study of copper(II) complexes incorporating pyridine,

*e-mail: ffj2003@163169.net thioether, imidazole and imine donors, which not only stem from their fascinating structures but also from their potential applications as new materials. ${ }^{10-13}$ The electrochemical and electrocatalytical properties of copper complexes with various different ligands have been investigated by several groups. $., 7,13,14$

Currently, triazoles and their derivatives, known for their rich coordination modes and wide applications as multidentate bridging ligands in coordination chemistry, are of considerable interest. ${ }^{15}$ However, to our best knowledge, the electrochemical and electrocatalytical study of copper complexes containing 1-butyl-1H-1,2,4-triazole is less reported. Our group has investigated the electrocatalytic activity of the zinc complex of 1-pentyl-1H-benzo[ $d]$ $[1,2,3]$ triazole toward the reduction of hydrogen peroxide. The objective of this work was to use two new copper(II) complexes, $\left[\mathrm{Cu}_{4} \mathrm{Cl} 6 \mathrm{O}_{6}\left(\mathrm{C}_{6} \mathrm{H}_{11} \mathrm{~N}_{3}\right)_{4}\right](\mathbf{1})$ and $\left[\mathrm{CuBr}_{2}\left(\mathrm{C}_{6} \mathrm{H}_{11} \mathrm{~N}_{3}\right)_{4}\right]$ (2), as bulk-modifiers to fabricate carbon paste electrodes by direct mixing. The two modified electrodes showed good electrocatalytic activities toward the reduction of hydrogen 
peroxide and trichloroacetic acid (TCA), and gave a low detection limit for hydrogen peroxide when compared with the zinc complex of 1-pentyl-1H-benzo[ $d][1,2,3]$ triazole. Possible mechanisms are proposed.

\section{Experimental}

\section{Chemicals and measurement}

All chemicals were of analytical reagent grade and used without further purification. Elemental compositions were determined with a Perkin-Elmer 1400C analyzer (USA). Infrared spectra were recorded on a Nicolet 170SX spectrometer (USA) using pressed $\mathrm{KBr}$ pellets in the $4000-400 \mathrm{~cm}^{-1}$ range. Electrochemical measurements were performed using an Autolab PGSTAT-30 digital potentiostat/galvanostat (EcoChemie BV, Utrecht, Netherlands). A three-electrode cell was used in the experiments. The working electrode was the modified $\mathrm{CPE}$, the counter electrode was a platinum wire and the reference electrode was $\mathrm{Ag} \mid \mathrm{AgCl} / \mathrm{KCl}\left(1 \mathrm{~mol} \mathrm{~L}^{-1}\right)$; all potentials reported in this work were measured relative to this electrode $\left(236.3 \mathrm{mV} / \mathrm{SHE}\right.$ at $\left.25^{\circ} \mathrm{C}\right)$. Britton-Robinson (B-R) buffer solution $\left(0.1 \mathrm{~mol} \mathrm{~L}^{-1}, \mathrm{pH}\right.$ 6.1) was used as the supporting electrolyte. All solutions were deaerated with pure nitrogen for 30 min and kept under $\mathrm{N}_{2}$ during the experiments. All measurements were performed at room temperature $\left(25 \pm 2{ }^{\circ} \mathrm{C}\right)$.

\section{Preparation and characterization of complexes 1 and $\mathbf{2}$}

Synthesis of complex $\mathbf{1}$ was performed as follows: copper(II) chloride dihydrate (170 mg, $1 \mathrm{mmol}$ ) and 1-butyl$1 H$-1,2,4-triazole ( $125 \mathrm{mg}, 1 \mathrm{mmol}$ ) were dissolved in $30 \mathrm{~mL}$ of ethanol. After stirring for $2 \mathrm{~h}$, the resulting tan precipitate was isolated by filtration. Recrystallization from acetonitrile gave a yield of $76 \%$. The $\mathrm{C}, \mathrm{H}$ and $\mathrm{N}$ contents were determined by elemental analysis (Found: C, 29.30; $\mathrm{H}, 4.52 ; \mathrm{N}, 17.08$. Calc. for $\mathrm{C}_{24} \mathrm{H}_{44} \mathrm{Cl}_{6} \mathrm{Cu}_{4} \mathrm{~N}_{12} \mathrm{O}: \mathrm{C}, 29.31$; $\mathrm{H}, 4.51 ; \mathrm{N}, 17.09 \%)$. In the IR spectra, the band at 3031 $\mathrm{cm}^{-1}$ was assigned to the $\mathrm{C}-\mathrm{H}$ stretching vibration of the ring of 1-butyl-1H-1,2,4-triazole. The bands at 2948 and $2871 \mathrm{~cm}^{-1}$ were attributed to the $\mathrm{C}-\mathrm{H}$ stretching vibration of the butyl chains. The band at $1283 \mathrm{~cm}^{-1}$ was attributed to the $\mathrm{C}-\mathrm{N}$ stretching vibration of triazole ring.

For the synthesis of complex 2, copper(II) bromide (225 mg, $1 \mathrm{mmol}$ ) and 1-butyl-1 H-1,2,4-triazole (125 mg, $1 \mathrm{mmol}$ ) were dissolved in $50 \mathrm{~mL}$ of ethanol. After stirring for $2 \mathrm{~h}$, the tan precipitate was isolated by filtration. Recrystallization from acetonitrile gave $82 \%$ yield. Elemental analysis for 2: Found: C, 39.79; H, 6.12; N,
23.22. Calc. for $\mathrm{C}_{24} \mathrm{H}_{44} \mathrm{Br}_{2} \mathrm{CuN}_{12}: \mathrm{C}, 39.81 ; \mathrm{H}, 6.13 ; \mathrm{N}$, $23.21 \%$.

X-ray diffraction analyses were carried out at $20{ }^{\circ} \mathrm{C}$ using $\operatorname{Mo} K_{\alpha}$ radiation $(\lambda=0.71073 \AA)$ with a graphite monochromator. The absorption correction applied to the collected data was empirical, based on $\psi$ scans. The structures of the two complexes, $\mathbf{1}$ and $\mathbf{2}$, were solved by direct methods and refined by least squares on $\mathrm{F}_{\text {obs }}{ }^{2}$ using the SHELXTL software package. ${ }^{16}$ All non-hydrogen atoms were refined anisotropically, and hydrogen atom positions were determined on the Fourier difference map and refined isotropically. The molecular graphics were plotted using SHELXTL. Atomic scattering factors and anomalous dispersion corrections were taken from the International Tables for X-ray Crystallography. ${ }^{17}$

\section{Preparation of $\mathrm{Cu}-\mathrm{CPE}$}

The traditional carbon paste electrode (CPE) was prepared by hand-mixing graphite powder and paraffin oil at a ratio of 70:30 (w/w) in an agate mortar. The modified CPEs were fabricated as follows: $0.3 \mathrm{~g}$ of graphite powder and $0.03 \mathrm{~g}$ of complex $\mathbf{1}$ or complex 2 were mixed and ground together using agate mortar and pestle for about $30 \mathrm{~min}$ to achieve an even, dry mixture. Paraffin oil $(0.1 \mathrm{~mL})$ was added to the mixture and stirred with a glass rod. Then the homogenized mixture was used to fill glass tubes ( $3 \mathrm{~mm}$ inner diameter) to a depth of $0.8 \mathrm{~cm}$. Electrical contact was established with a copper rod and the surface of the $\mathrm{Cu}-\mathrm{CPE}$ was polished on a piece of weighing paper to a mirror finish just before use.

The different quality ratios of graphite powder and the complexes were investigated to determine the optimum preparation condition. We investigated the graphite powder and the title complexes at the ratios of 20:1, 14:1, 10:1, 8:1 and $5: 1(\mathrm{~m} / \mathrm{m})$, and found the 10:1 ratio optimal. When the amount of the complex was too low, the electrochemical signal was weak. Conversely, when the amount of the title complex was high, the conductivity of the modified carbon paste electrode was low.

\section{Results and Discussion}

\section{Crystal structures of complexes 1 and $\mathbf{2}$}

Crystal and structure refinement data for the two complexes are listed in Table 1. The molecular structure of complex 1 with the atomic numbering scheme is shown in Figure 1. The four copper(II) atoms have similar coordination environment. Each copper atom has slightly distorted trigonal bipyramidal geometry 
Table 1. Crystal data and structure refinement for complexes $\mathbf{1}$ and $\mathbf{2}$

\begin{tabular}{|c|c|c|}
\hline Empirical formula & $\mathrm{C}_{24} \mathrm{H}_{44} \mathrm{Cl}_{6} \mathrm{Cu}_{4} \mathrm{~N}_{12} \mathrm{O}$ (complex $\mathbf{1}$ ) & $\mathrm{C}_{24} \mathrm{H}_{44} \mathrm{Br}_{2} \mathrm{CuN}_{12}($ complex 2) \\
\hline Formula weight & 983.60 & 724.07 \\
\hline Temperature (K) & $293(2)$ & $293(2)$ \\
\hline Wavelength $(\AA)$ & 0.71073 & 0.71073 \\
\hline Crystal system, space group & Monoclinic, $P 2_{1} / \mathrm{c}$ & Triclinic, $P_{l}^{-}$ \\
\hline \multicolumn{3}{|l|}{ Unit cell dimensions } \\
\hline$a(\AA)$ & $21.53(2)$ & $7.774(2)$ \\
\hline$b(\AA)$ & $13.980(2)$ & $8.756(2)$ \\
\hline$c(\AA)$ & $13.852(9)$ & $13.847(4)$ \\
\hline$\alpha\left(^{\circ}\right)$ & $89.97(2)$ & $102.168(5)$ \\
\hline$\beta\left(^{\circ}\right)$ & $107.49(2)$ & $95.536(5)$ \\
\hline$\gamma\left({ }^{\circ}\right)$ & $90.12(2)$ & $113.846(3)$ \\
\hline Volume $\left(\AA^{3}\right)$ & $3977(4)$ & $825.2(3)$ \\
\hline $\mathrm{Z}$, Calculated density $\left(\mathrm{g} \mathrm{cm}^{-3}\right)$ & $4,1.648$ & $1,1.457$ \\
\hline Absorption coefficient $\left(\mathrm{mm}^{-1}\right)$ & 2.551 & 3.117 \\
\hline $\mathrm{F}(000)$ & 2004 & 371 \\
\hline Theta range for data collection $\left(^{\circ}\right)$ & 1.76 to 28.43 & 1.54 to 28.43 \\
\hline Limiting indices & $-28 \leq \mathrm{h} \leq 20,-18 \leq \mathrm{k} \leq 16,-11 \leq 1 \leq 18$ & $-10 \leq \mathrm{h} \leq 9,-11 \leq \mathrm{k} \leq 10,-18 \leq 1 \leq 18$ \\
\hline Reflections collected / unique & $16735 / 8695\left[R_{(\mathrm{int})}=0.0972\right]$ & $5248 / 3803\left[R_{(\mathrm{int})}=0.0305\right]$ \\
\hline Completeness to $\theta=28.43(\%)$ & 95.8 & 91.4 \\
\hline Data / restraints / parameters & 8695 / 0 / 424 & $3803 / 0 / 178$ \\
\hline Goodness-of-fit on $F^{2}$ & 0.983 & 0.949 \\
\hline Final $R$ indices $[\mathrm{I}>2 \sigma(\mathrm{I})]$ & $\mathrm{R}_{1}=0.0764, \mathrm{wR}_{2}=0.2193$ & $\mathrm{R}_{1}=0.0512, \mathrm{wR}_{2}=0.1063$ \\
\hline $\mathrm{R}$ indices (all data) & $\mathrm{R}_{1}=0.1405, \mathrm{wR}_{2}=0.2947$ & $\mathrm{R}_{1}=0.1277, \mathrm{wR}_{2}=0.1342$ \\
\hline Largest diff. peak and hole (e $\left.\AA^{-3}\right)$ & 1.652 and -1.225 & 0.635 and -0.545 \\
\hline
\end{tabular}

with three $\mu_{2}-\mathrm{Cl}$ atoms in equatorial positions and the interstitial $\mathrm{O}$ atom and one $\mathrm{N}$ atom from 1-butyl-1 $H$ 1,2,4-triazole ligand occupying the axial positions. The $\mathrm{Cu}-\mathrm{Cu}$ bond lengths (3.0942-3.1252 $\AA$ ) are comparable with those found in a similar compound. ${ }^{18}$ The six $\mathrm{Cu}-\mathrm{Cl}-\mathrm{Cu}$ bond angles range from $76.52(1)^{\circ}$ to $79.40(2)^{\circ}$. The $\mathrm{Cu}-\mathrm{N}$ bond lengths (1.96-1.98 $\AA$ ) are similar and consistent with an earlier report. ${ }^{19}$ There are potentially weak intramolecular hydrogen bonds interactions,

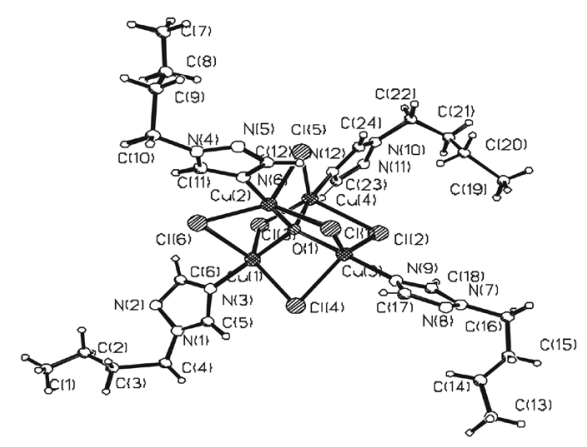

Figure 1. ORTEP drawing of complex 1 with partial atomic numbering. and the donor-acceptor distances are $3.0400 \AA$ for $\mathrm{C}(2) \cdots \mathrm{N}(2), 3.3007 \AA$ for $\mathrm{C}(5) \cdots \mathrm{Cl}(4)$ and $2.9644 \AA$ for $\mathrm{C}(20) \cdots \mathrm{N}(10)$. There are $\pi-\pi$ stacking interactions and $\mathrm{C}-\mathrm{H} \cdots \pi$ supramolecular interactions but no classic hydrogen bonds in the lattice. In the solid state, the intermolecular interactions stabilize the crystal structure.

The molecular structure of complex $\mathbf{2}$ is shown in Figure 2 with the atom numbering scheme. The copper atom adopts a distorted octahedron geometry with two bromides and four nitrogen donor atoms from the 1-butyl-1H-1,2,4triazole ligands. The $\mathrm{Cu}-\mathrm{Br}$ distances are elongated due to Jahn-Teller distortion. ${ }^{20}$ The $\mathrm{Cu}-\mathrm{N}$ distances of 2.000 (4) and 2.043 (3) $\AA$ are comparable with corresponding values in a similar complex. ${ }^{20}$ There are potentially weak intramolecular hydrogen bonds interactions, and the donor-acceptor distances are $3.4645 \AA$ for $\mathrm{C}(5) \cdots \mathrm{Br}(1)$ and $3.5222 \AA$ for $\mathrm{C}(6) \cdots \mathrm{Br}(1)$. There is also intermolecular hydrogen bonding, with a donor-acceptor distance of $3.6736 \AA$ for $\mathrm{C}(11) \cdots \mathrm{Br}(1)$. There are $\pi-\pi$ stacking interactions and $\mathrm{C}-\mathrm{H} \cdots \pi$ supramolecular interactions that stabilize the crystal structure in the solid state. 


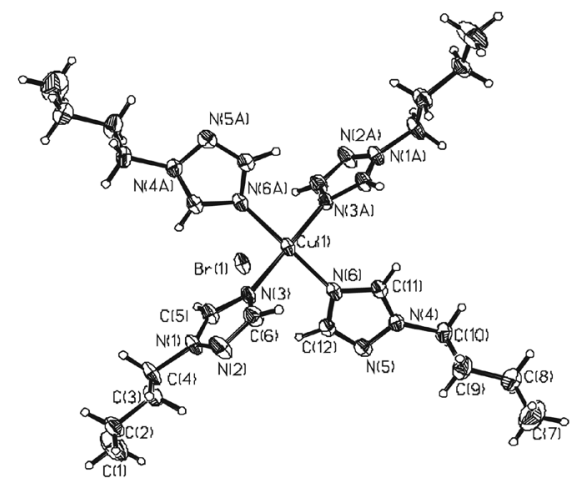

Figure 2. ORTEP drawing of complex 2 with partial atomic numbering.

\section{Electrochemical behavior of $\mathrm{Cu}-\mathrm{CPE}$}

The cyclic voltammograms (CVs) of 1-CPE and 2-CPE are presented in Figure 3. In the potential range of 0 to $-1.6 \mathrm{~V}$ for 1 -CPE, when the scan rate is $0.10 \mathrm{~V} \mathrm{~s}^{-1}$, the curve $a$ shows a couple of redox peaks at $-0.825 \mathrm{~V}$ and $-0.714 \mathrm{~V}$, with the formal potential at $-0.77 \mathrm{~V}$, corresponding to the electrochemical process of $\mathrm{Cu}^{\mathrm{I}} / \mathrm{Cu}^{\mathrm{I}}$. The separation of the cathodic and anodic peak potentials $(\Delta \mathrm{E})$ is $0.111 \mathrm{~V}$, with $\mathrm{i}_{\mathrm{pc}} / \mathrm{i}_{\mathrm{pa}}=1.05$. For 2-CPE, the curve $b$ also presents a couple of redox peaks at $-0.795 \mathrm{~V}$ and $-0.684 \mathrm{~V}$, with the formal potential at $-0.74 \mathrm{~V}$, corresponding to the electrochemical process of $\mathrm{Cu}^{\mathrm{I} /} / \mathrm{Cu}^{\mathrm{I}}$. The separation of the cathodic and anodic peak potentials $(\Delta \mathrm{E})$ is $0.111 \mathrm{~V}$, with $\mathrm{i}_{\mathrm{pc}} / \mathrm{i}_{\mathrm{pa}}=1.03$, indicating that the electrochemical behavior of complex 2 on the electrode is quasireversible.

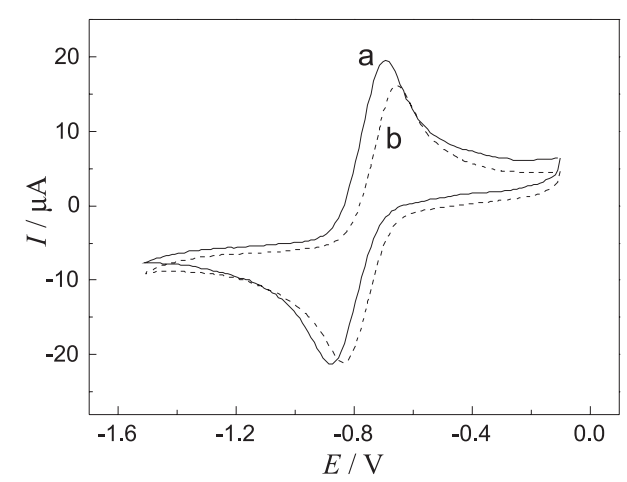

Figure 3. Cyclic voltammograms registered for 1-CPE (curve a) and 2-CPE (curve b) in $0.1 \mathrm{~mol} \mathrm{~L}^{-1} \mathrm{~B}-\mathrm{R}$ buffer solution, $\mathrm{pH}$ 6.1, with the scan rate as $0.10 \mathrm{~V} \mathrm{~s}^{-1}$.

From these results, we conclude that the two modified CPEs have similar cyclic voltammetry behaviors. So we further investigated the CVs of 2-CPE at different scan rates (Figure 4). When the scan rate was varied from 0.03 to $0.24 \mathrm{~V} \mathrm{~s}^{-1}$, the peak potentials changed gradually; the cathodic peak potentials shifted to the negative direction and the corresponding anodic peak potentials shifted to the positive direction with increasing scan rate. The plot of peak current $v s$. scan rate is shown in the inset of Figure 4. The anodic and cathodic currents are proportional to the scan rate, suggesting that the redox process is confined to the surface.

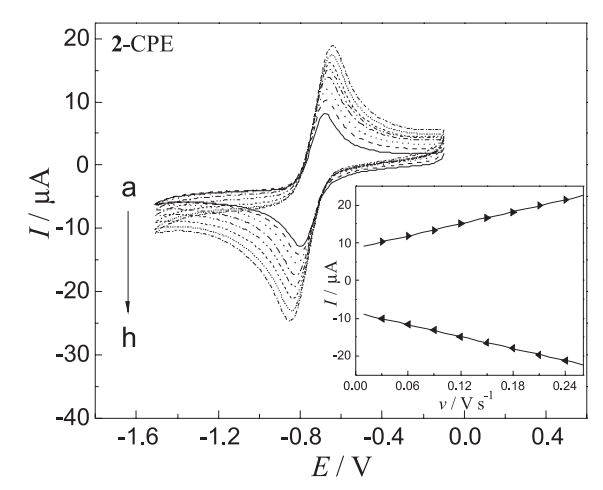

Figure 4. Cyclic voltammograms registered for 2-CPE in $0.1 \mathrm{~mol} \mathrm{~L}^{-1}$ $\mathrm{B}-\mathrm{R}$ buffer solution, $\mathrm{pH}$ 6.1. Curves (a-h) correspond to the scan rates $0.03,0.06,0.09,0.12,0.15,0.18,0.21$ and $0.24 \mathrm{~V} \mathrm{~s}^{-1}$. Inset: peak current $v s$. the scan rate.

\section{Electrocatalytic activity of 2-CPE}

\section{Electrocatalytic effect on reduction of hydrogen peroxide}

Determination of hydrogen peroxide is of practical importance because $\mathrm{H}_{2} \mathrm{O}_{2}$ is the product of reactions catalyzed by a large number of oxidases; it is also essential in food, pharmaceutical and environmental analyses. ${ }^{21} \mathrm{As}$ it is known, the electroreduction of hydrogen peroxide requires a large overpotential and no obvious response is observed on a bare CPE.

Herein we report the electrocatalytic activities of the 2-CPE, while the electrocatalytic results obtained for 1-CPE are presented in the Supplementary Information. Figure 5 shows the electrocatalytic activity of 2-CPE toward the reduction of hydrogen peroxide (curves a-f). The oxidation and reduction peak potentials had no obvious change, which suggested that complex 2 was stable. The reduction peak currents increased markedly while the corresponding oxidation peak decreased. When the concentration of hydrogen peroxide was increased to $0.20 \mu \mathrm{mol} \mathrm{L} \mathrm{L}^{-1}$, the maximum value of the reduction peak current was obtained, while the value of the oxidation peak current was almost reduced to zero. This result indicates that 2-CPE shows good electrocatalytic activity toward the reduction of hydrogen peroxide. The possible reaction processes could be described using the following equations: ${ }^{22,6}$

$\mathrm{Cu}^{\mathrm{II}}+\mathrm{e}^{-} \rightarrow \mathrm{Cu}^{\mathrm{I}}$

$2 \mathrm{Cu}^{\mathrm{I}}+\mathrm{H}_{2} \mathrm{O}_{2}+2 \mathrm{H}^{+} \rightarrow 2 \mathrm{Cu}^{\mathrm{II}}+2 \mathrm{H}_{2} \mathrm{O}$ 
The inset of Figure 5 shows that the catalytic current is linear $v s$. hydrogen peroxide concentration in the range of $0.02-0.20 \mu \mathrm{mol} \mathrm{\textrm {L } ^ { - 1 }}$. The linear regression equation is $I_{p c}(\mu \mathrm{A})=-98.80 \mathrm{C}\left(\mu \mathrm{mol} \mathrm{L} \mathrm{L}^{-1}\right)-20.83$ with a correlation coefficient of 0.996 . The detection limit (signal to noise is 3 ) and the sensitivity are $0.01 \mu \mathrm{mol} \mathrm{L} \mathrm{L}^{-1}$ and $98.80 \mu \mathrm{A} \mu \mathrm{mol} \mathrm{L} \mathrm{L}^{-1}$, respectively. This value (detection limit) is much lower than those described in earlier reports using other modified electrodes. ${ }^{21,23,24}$

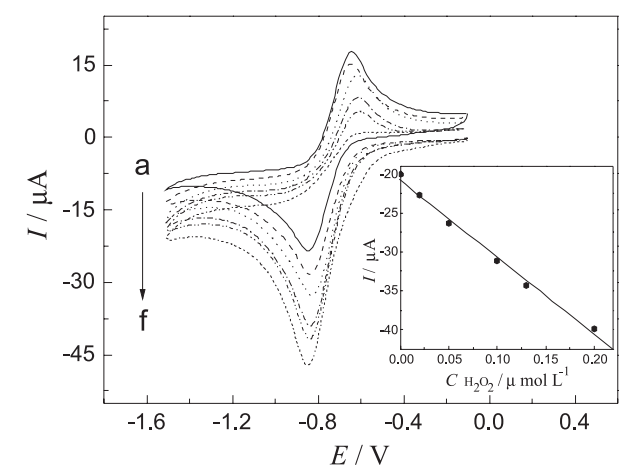

Figure 5. Cyclic voltammograms for 2-CPE in $0.1 \mathrm{~mol} \mathrm{~L}^{-1} \mathrm{~B}-\mathrm{R}$ buffer solution, $\mathrm{pH} 6.1$, containing (a-f) $0,0.02,0.05,0.10,0.13$ and $0.20 \mu \mathrm{mol} \mathrm{L}{ }^{-1} \mathrm{H}_{2} \mathrm{O}_{2}$. Scan rate: $0.05 \mathrm{~V} \mathrm{~s}^{-1}$. Inset: cathodic peak current vs. $\mathrm{H}_{2} \mathrm{O}_{2}$ concentration.

\section{Electrocatalytic reduction of trichloroacetic acid}

Organohalides are environmental pollutants and TCA is formed in water chlorination. Electrochemical oxidation or reduction is an effective measure to deal with pollutants. The advantages of the electrochemical methods are that new pollutants can not be introduced and there is no separation problem. ${ }^{8}$ Some insoluble metal complexes containing redox mediators can be used for electrocatalysis.

The electrocatalytic activity of 2-CPE toward TCA is presented in Figure 6. With the addition of TCA to the solution (curves a-e), the oxidation and reduction peak potentials had no obvious change, however, there was a dramatic enhancement of the cathodic peak current, while the anodic peak current decreased. When the concentration of TCA reached $0.20 \mu \mathrm{mol} \mathrm{L} \mathrm{L}^{-1}$, the maximum value of the reduction peak current was obtained, while the value of the oxidation peak current was almost reduced to zero. This result indicates that 2-CPE shows a strong catalytic effect toward the reduction of TCA. The possible reaction processes could be described using the following equations: ${ }^{22}$

$$
\mathrm{Cu}^{\mathrm{II}}+\mathrm{e}^{-} \rightarrow \mathrm{Cu}^{\mathrm{I}}
$$

$2 \mathrm{Cu}^{\mathrm{I}}+\mathrm{CCl}_{3} \mathrm{COOH}+\mathrm{H}^{+} \rightarrow 2 \mathrm{Cu}^{\mathrm{II}}+\mathrm{CHCl}_{2} \mathrm{COOH}+\mathrm{Cl}^{-}$
The inset of Figure 6 shows that the catalytic current is linear vs. TCA concentration in the range of $0.02-0.20 \mu \mathrm{mol} \mathrm{L}^{-1}$. The linear regression equation is $\mathrm{I}_{\mathrm{pc}}(\mu \mathrm{A})=-80.05 \mathrm{C}\left(\mu \mathrm{mol} \mathrm{L} \mathrm{L}^{-1}\right)$ -16.55 with a correlation coefficient of 0.997 . The detection limit (signal to noise is 3 ) and the sensitivity are $0.01 \mu \mathrm{mol} \mathrm{L}^{-1}$ and $80.05 \mu \mathrm{A} \mu \mathrm{mol} \mathrm{L} \mathrm{L}^{-1}$, respectively.

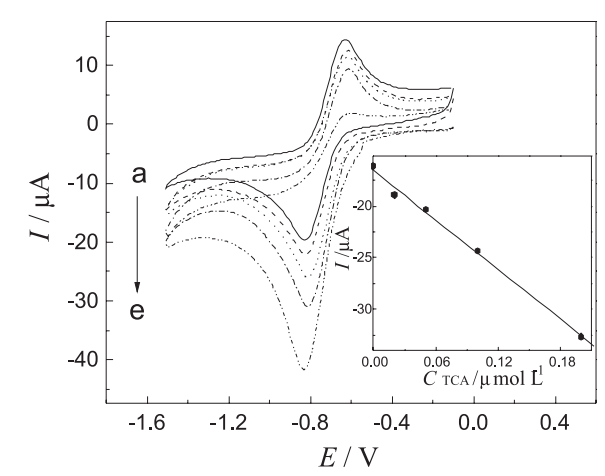

Figure 6. Cyclic voltammograms for 2-CPE in $0.1 \mathrm{~mol} \mathrm{~L}^{-1} \mathrm{~B}-\mathrm{R}$ buffer solution, pH 6.1, containing (a-e) 0, 0.02, 0.05, 0.10 and $0.20 \mu \mathrm{mol} \mathrm{L}^{-1} \mathrm{TCA}$. Scan rate: $0.05 \mathrm{~V} \mathrm{~s}^{-1}$. Inset: cathodic peak current $v s$. TCA concentration.

The electrocatalytic activities toward the reduction of hydrogen peroxide and trichloroacetic acid of the 1-CPE electrode are presented as Supplementary Information (Figures S1 and S2). The detection limit, linear calibration

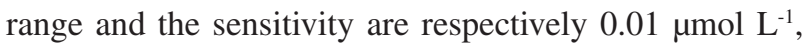

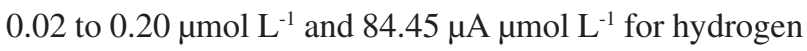
peroxide detection, and $0.01 \mu \mathrm{mol} \mathrm{L}^{-1}, 0.02$ to $0.15 \mu \mathrm{mol} \mathrm{L}{ }^{-1}$ and $84.73 \mu \mathrm{A} \mu \mathrm{mol} \mathrm{L} \mathrm{L}^{-1}$ for TCA detection. These results confirm that both chemically modified electrodes show similar cyclic voltammetry behaviors and electrocatalytic activities.

Compared with other modified film electrodes, the two electrodes described in this work show high stability. In our experiments, after the electrocatalytic reaction, 2-CPE was investigated in buffer solution under the same conditions shown in Figure 4. We found that the peak potentials and peak currents had no obvious change, which suggested that no new materials appeared. This indicates that complexes $\mathbf{1}$ and $\mathbf{2}$ are stable and play a catalytic role during the reactions. When the potential is maintained in the same range, 2-CPE is stable over 200 cycles at $0.10 \mathrm{~V} \mathrm{~s}^{-1}$ and the current response remains almost unchanged. When the modified CPEs are stored at room temperature for at least two months, the current response decreases only by $2.1 \%$.

\section{Conclusions}

In summary, the two new copper(II) complexes $\left[\mathrm{Cu}_{4} \mathrm{Cl}_{6} \mathrm{O}\left(\mathrm{C}_{6} \mathrm{H}_{11} \mathrm{~N}_{3}\right)_{4}\right]$ and $\left[\mathrm{CuBr}_{2}\left(\mathrm{C}_{6} \mathrm{H}_{11} \mathrm{~N}_{3}\right)_{4}\right]$ were 
synthesized and characterized by X-ray diffractometry, IR spectroscopy and elemental analysis. They were employed in the preparation of chemically modified CPEs, and their electrochemical and electrocatalytic behavior was investigated. Both complexes showed good electrocatalytic activities toward the reduction of hydrogen peroxide and trichloroacetic acid, and the results were reproducible with a lower detection limit than described in earlier reports, which may be suitable for the quantitative analysis of environmentally hazardous materials. The advantages of these bulk-modified $\mathrm{Cu}^{\mathrm{II}}$-CPEs are their high stability, excellent catalytic activity, low detection limit and simplicity of preparation in comparison with other methods. These points are of relevance for practical applications.

\section{Supplementary Information}

Supplementary data (additional information on the electrocatalytic activities of 1-CPE and Figures S1-S2) are available free of charge at http://jbcs.sbq.org.br, as a PDF file.

Crystallographic data have been deposited with the Cambridge Crystallographic Data Centre (CCDC). Copies can be obtained free of charge via www.ccdc.cam.ac.uk/ conts/retrieving.html or from the CCDC, 12 Union Road, Cambridge CB2 1EZ, UK (fax: +44 1223336033 or e-mail: deposit@ccdc.cam.ac.uk), quoting the deposition numbers CCDC 703828 (complex 1) and 702328 (complex 2).

\section{Acknowledgements}

This work was supported by the Natural Science Foundation of Shandong Province (No.Z2007B01), P. R. China.

\section{References}

1. Kalcher, K.; Kauffmann, J. M.; Wang, J.; Svancara, I.; Vytras, K.; Neuhold, C.; Yang, Z.; Electroanalysis 1995, 7, 5.

2. Svancara, I.; Vytras, K.; Barek, J.; Crit. Rev. Anal. Chem. 2001, 31,311 .

3. Zen, J. M.; Kumar, A. S.; Tsai, D. M.; Electroanalysis 2003, 15,1073 .
4. Wang, X. L.; Kang, Z. H.; Wang, E. B.; Hu, C. W.; J. Electroanal. Chem. 2002, 523, 142.

5. Wang, X. L.; Wang, E. B.; Lan, Y.; Hu, C. W.; Electroanalysis 2002, 14, 15 .

6. Wang, X. L.; Zhao, H. Y.; Lin, H. Y.; Liu, G. C.; Fang, J. N.; Chen, B. K.; Electroanalysis 2008, 20, 1055.

7. Wang, X. L.; Lin, H. Y.; Liu, G. C.; Zhao, H. Y.; Chen, B. K.; J. Organomet. Chem. 2008, 693, 2767.

8. Jiang, X. E.; Guo, L. P.; Du, X. G.; Talanta 2003, 61, 247.

9. Filho, O. F.; Dockal, E. R.; Junior, L. H. M.; Teixeira, M. F. S.; Anal. Lett. 2007, 40, 1825.

10. Balamurugan, R.; Palaniandavar, M.; Halcrow, M. A.; Polyhedron 2006, 25, 1077.

11. Kim, E. H.; Kim, D. I.; Lee, H. S.; Byun, J. C.; Choi, J. H.; Park, Y. C.; Polyhedron 2007, 26, 85.

12. Gao, G. G.; Xu, L.; Wang, W. J.; An, W. J.; Qiu, Y. F.; Wang, Z. Q.; Wang, E. B.; J. Phys. Chem. B 2005, 109, 8948.

13. Salimi, A.; Alizadeh, V.; Hadadzadeh, H.; Electroanalysis 2004, 16, 1984.

14. Chen, S. M.; J. Electroanal. Chem. 1998, 457, 23.

15. Liu, J. J.; He, X.; Shao, M.; Li, M. X.; J. Mol. Struct. 2008 , 891,50 .

16. Sheldrick, G. M.; SHELXTL. Version 6.10. Bruker AXS Inc., Madison, Wisconsin, USA, 2000.

17. Wilson, A. J.; International Table for X-ray Crystallography; V. C. Kluwer Academic Publishers, Dordrecht, 1992, Table 6.1.1.4, p 500, Table 4.2.6.8, p. 219.

18. Jones, D. H.; Sams, J. R.; Thompson, R. C.; J. Chem. Phys. 1983, 79, 3877.

19. Jian, F. F.; Zhao, P. S.; Wang, H. X.; Lu, L. D.; Bull. Korean Chem. Soc. 2004, 25, 673.

20. Näther, C.; Wriedt, M.; Jess, I.; Acta Crystallogr., Sect. E: Struct. Rep. Online 2002, 58, m39.

21. Wang, B.; Dong, S.; Talanta 2000, 51, 565.

22. Li, Y.; Lin, X.; Jiang, C.; Electroanalysis, 2006, 18, 2085.

23. Sun, N. J.; Guan, L. H.; Shi, Z. J.; Li, N. Q.; Gu, Z. N.; Zhu, Z. W.; Li, M. X.; Shao, Y. H.; Anal. Chem. 2006, 78, 6050.

24. Karyakin, A. A.; Puganova, E. A.; Budashov, I. A.; Kurochkin, I. N.; Karyakina, E. E.; Levchenko, V. A.; Matveyenko, V. N.; Varfolomeyev, S. D.; Anal. Chem. 2004, 76, 474.

Received: April 22, 2009 Web Release Date: December 15, 2009 


\title{
Two New Copper(II) Complexes of 1-Butyl-1H-1,2,4-triazole: Synthesis, Characterization and Electrocatalytic Activity
}

\author{
Ke Fei Wang, Fang Fang Jian* and Rui Rui Zhuang
}

New Materials \& Function Coordination Chemistry Laboratory, Qingdao University of Science and Technology, Qingdao Shandong 266042, People's Republic of China

Electrocatalytic activity of the 1-CPE modified electrode

The electrocatalytic activities of 1-CPE toward the reduction of hydrogen peroxide and trichloroacetic acid are presented in Figures $\mathrm{S} 1$ and $\mathrm{S} 2$. The detection limit, linear calibration range and the sensitivity are respectively $0.01 \mu \mathrm{mol} \mathrm{L}^{-1}, 0.02$ to

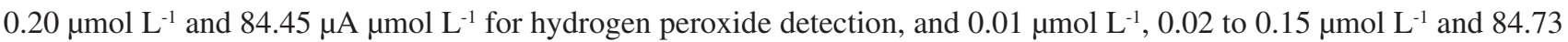
$\mu \mathrm{A} \mu \mathrm{mol} \mathrm{L} \mathrm{L}^{-1}$ for TCA detection. These results indicate that 1-CPE and 2-CPE show similar cyclic voltammetry behaviors and electrocatalytic activities.

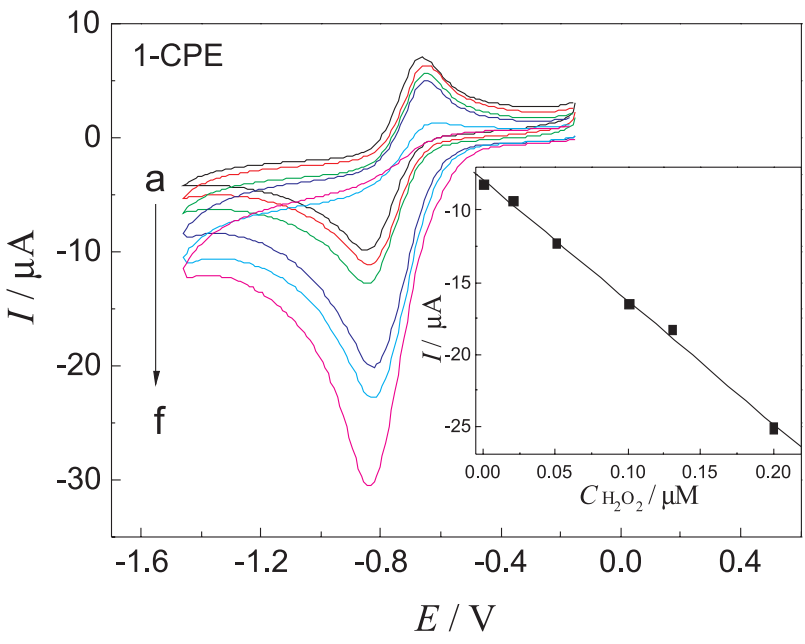

Figure S1. Cyclic voltammograms for 1-CPE in $0.1 \mathrm{~mol} \mathrm{~L}^{-1} \mathrm{~B}-\mathrm{R}$ buffer solution, $\mathrm{pH}$ 6.1, containing (a-f) 0, 0.02, 0.05, 0.10, 0.13 and $0.20 \mu \mathrm{mol} \mathrm{L}^{-1} \mathrm{H}_{2} \mathrm{O}_{2}$. Scan rate: $0.05 \mathrm{~V} \mathrm{~s}^{-1}$. Inset: cathodic peak current vs. $\mathrm{H}_{2} \mathrm{O}_{2}$ concentration.

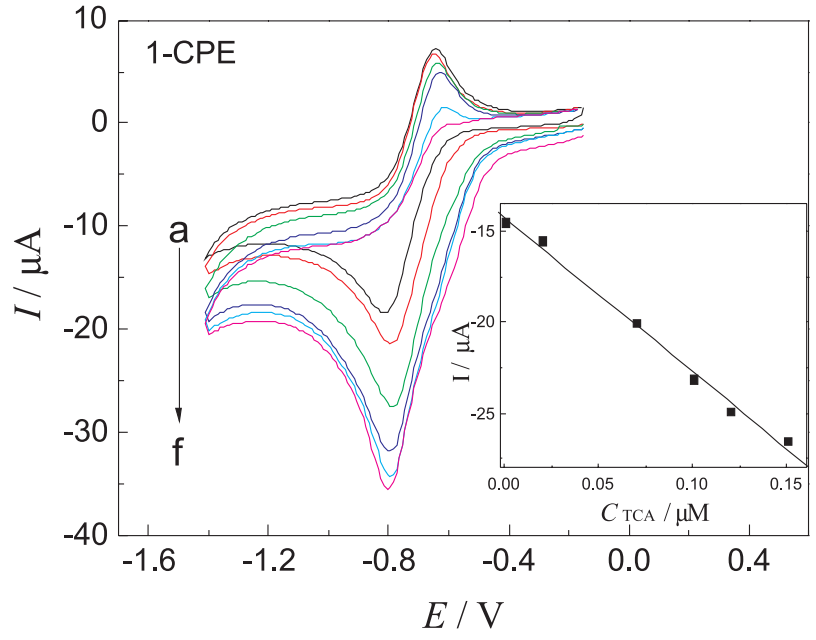

Figure S2. Cyclic voltammograms for 1-CPE in $0.1 \mathrm{~mol} \mathrm{~L}^{-1} \mathrm{~B}-\mathrm{R}$ buffer solution, pH 6.1, containing (a-f) 0, 0.02, 0.07, 0.10, 0.12 and $0.15 \mu \mathrm{mol} \mathrm{L} \mathrm{L}^{-1} \mathrm{TCA}$. Scan rate: $0.05 \mathrm{~V} \mathrm{~s}^{-1}$. Inset: cathodic peak current $v s$. TCA concentration. 